\title{
Possible Fisherian Changes in Female Mate-Choice Criteria in a Mass-Reared Strain of Ceratitis capitata (Diptera: Tephritidae)
}

\author{
R. D. BRICEÑO ${ }^{1}$ AND IVILL1AM G. EBERHARD ${ }^{1,2}$
}

\begin{abstract}
Ann. Entomol. Soc. Am. 93(2): 343-345 (2000)
ABSTRACT The frequent interruption of male courtship in highly crowded mass-rearing cages of Ceratitis capitata (Wiedemann) was correlated with changes in both male courtship and female acceptance criteria in a mass-reared Costa Rican strain, in accord with previous studies of other strains. Abbreviation of courtship behavior by mass-reared males was associated with the loss of the wild-type female tendency to reject males that performed shorter courtships. Consideration of probable costs and benefits of female choice in mass-rearing cages suggests that inadvertant selection in the cages probably favored the change in female criteria because females obtained sons with more effective courtship behavior.
\end{abstract}

KEY WORDS Mediterranean fruit fly, Ceratitis capitata, Fisherian sexual selection, courtship, mass-rearing

\begin{abstract}
MediterRanean FrutT Flies, Ceratitis capitata (Wiedemanı), are reared in massive numbers to combat pest populations. Because it is difficult to induce wild flies to reproduce in captivity (Rössler 1975), some strains have been maintained under mass-rearing conditions for many years. These conditions differ from those in the wild in a number of respects (Cayol 1999); therefore, old mass-reared strains represent evolutionary experiments in responses to mass-rearing conditions. Several adult traits, including timing of sexual maturity, sperm length, male courtship behavior, and female oviposition behavior have changed in massreared strains (Cayol 1999).
\end{abstract}

The sexual behavior of male C. capitata (Eberhard 1999) involves courtship of females before mounting that includes visual, auditory, and chemical stimuli. If the female cooperates, the male leaps onto her back and attempts to copulate. A female can, and often does, reject males by either failing to position herself appropriately or by flying as soon as the male leaps onto her dorsum. In the wild, most C. capitata matings occur at leks, where each male is on a different leaf of a tree or bush, and direct interference during courtship is rare. In contrast, under the extremely crowded conditions of mass-rearing cages $\left(\approx 2 \mathrm{~cm}^{2}\right.$ of resting space per fly), more than half of courtships are interrupted by the arrival of another fly.

Males of both a Costa Rican mass-reared strain and the wild strain from which it was derived facultatively adjust to crowded conditions by shortening the duration of their premount courtship (Briceño and Eberhard 1998). In addition, males of the mass-reared strain perform shorter courtships than do wild males, both

\footnotetext{
${ }^{1}$ Escuela de Biología, Universidad de Costa Rica, Ciudad Universitaria Costa Rica

${ }^{2}$ Smithsonian Tropical Research Institute, Escuela De Biologia, Universidad de Costa Rica, Ciudad Universitaria, Costa Rica.
}

when paired in isolation with mass-reared females and with wild females (Briceño and Eberhard 1998). These data, plus the relatively short premount courtships of males of a 2 nd Costa Rican mass-reared strain and of another mass-reared strain derived from Egyptian flies (Briceño and Eberhard 1998), indicate that mass-reared males have evolved shorter courtship times because of the selection against protracted courtship that results from interruptions under massrearing conditions. In this study we present data on the female side of these interactions, documenting the effects of courtship duration on the rates of mate acceptance by wild and mass-reared females.

\section{Materials and Methods}

Wild flies were raised from infested oranges and tangerines collected during March and April 1996 near the towns of Alajuela, Grecia, and San Ramon, Alajuela Province, Costa Rica, and held over sawdust until the larvae emerged to pupate. Adult flies were separated by sex before they were $24 \mathrm{~h}$ old, and held for $5 \mathrm{~d}$ in groups of 40-50 flies per cage in screened cages ( 30 by 30 by $30 \mathrm{~cm}$ ) with free access to water and hydrolyzed protein with sugar before being observed.

Mass-reared flies were from a strain derived from flies collected in the same zone $6 \mathrm{yr}$ previously $(\approx 78$ generations), and maintained subsequently as adults in mass-rearing cages ( 2.70 by 0.70 by $0.33 \mathrm{~m}$ ) with $\approx 60,000$ flies per cage. Adults were also separated by sex before they were $24 \mathrm{~h}$ old and held as above until being video taped when they were at least $5 \mathrm{~d}$ old. All pairs involved individuals of the same strain (wild $x$ wild, or mass-reared $\times$ mass-reared).

In 1 set of observations, pairs of virgin flies to be observed were placed in plastic petri dishes $(13.7 \mathrm{~cm}$ diameter and $1.8 \mathrm{~cm}$ deep) in which cardboard walls formed 4 equal-sized chambers $\left(84 \mathrm{~cm}^{3}\right.$ each). With 1 
pair in each chamber, the petri dish was placed on a sheet of glass, and the flies' behavior was taped from below using a Sony (Tokyo, Japan) His CCD-TR700 with +6 closeup lenses in artificial light at room temperature. Each taping session began at 0900 hours and lasted $6 \mathrm{~h}$. All 8 flies were visible at all times in the video images, except during the brief closeup sequences taken of flies that were apparently copulating to check whether the male had achieved intromission. In a 2nd set of observations, there was only a single pair of flies in each petri dish, and taping began when male-female courtship interactions commenced.

Courtships followed by mounts that resulted in copulation were judged successful; courtships that led to mounts that did not result in copulation were judged unsuccessful. Only the 1st uninterrupted courtship that led to a mount was analyzed for each pair of flies. Overt female resistance to mounts took the form of buzzing her wings briefly, or, in more energetic resistance, of flying and colliding repeatedly with the walls of the chamber. Flights of this sort inevitably result in failure to copulate (Whittier et al. 1994). Less obvious resistance also occurred when the male was unable to intromit even after repeated sustained genitalic contact. These failures were probably the result of female failure to evert her aculeus and thus allow genitalic clasping (Eberhard and Pereira 1995), but this detail was not visible in the video images.

Initiation of premount courtship was designated as the moment the male changed from a calling position with the tip of his abdomen elevated, his rectal pouch everted, and his wings quiet (phase 1 of Feron 1962) to continuous wing vibration with the tip of his abdomen bent ventrally as he faced the female (phase II of Feron 1962). Premount courtship ended the moment the male leapt onto the female.

Average values for durations are given followed by 1 standard deviation. The data were not normally distributed, however, and all statistical tests used the nonparametric Mann-Whitney $U$ test.

\section{Results}

In the 1st set of observations, mounts by wild males that failed to result in copulation were preceded by significantly shorter premount courtships $(x=10.31 \pm$ $13.76 \mathrm{~s}, n=43)$ than were mounts that resulted in copulation $(x=12.43 \pm 13.41 \mathrm{~s}, n=58, P=0.01)$. $\ln$ mass-reared flies, in contrast, there was no difference (respective means were $10.86 \pm 9.44 \mathrm{~s}, n=383$, and $10.88 \pm 10.91 \mathrm{~s}, n=360, P=0.77$ ). As in a previous study based on other observations (Briceño and Eberhard 1998), premount courtships by mass-reared males were significantly shorter than those of wild males (respective means for successful and unsuccessful courtships combined were $10.83 \pm 10.12 \mathrm{~s}, n=743$, and $11.28 \pm 16.59 \mathrm{~s}, n=101, P=0.011$ ).

Similar patterns occurred in the 2nd set of data. The mean duration of successful courtships of wild females $(23.20 \pm 22.25 \mathrm{~s}, n=34)$ was longer than that of unsuccessful courtships $(18.01 \pm 19.45 \mathrm{~s}, n=68, P<0.05)$. In contrast, the mean durations of successful and unsuccessful courtships of mass-reared females did not differ
$(16.08 \pm 16.30 \mathrm{~s}, n=32$, versus $15.76 \pm 11.85 \mathrm{~s}, n=206$, $P=0.17)$. Counting both successful and unsuccessful premount courtships, means for wild flies were greater than those for mass-reared flies (20.19 $\pm 20.72 \mathrm{~s}, n=102$ and $15.81 \pm 12.57 \mathrm{~s}, n=236$, respectively, $P<0.05$ ).

\section{Discussion}

Both sets of observations indicate that mass-reared females have lost the tendency present in wild females to reject males when premount courtship is shorter. The apparent loss of female acceptance criteria favoring longer courtships probably resulted from changes accompanying selection in mass-rearing cages that favored shorter courtships (Briceño and Eberhard 1998; Miyatake and Haraguchi 1996). It seems probable that those females more likely to respond favorably to short premount courtships were favored because of the advantage of having sons with shorter premount courtship behavior. Most of the other possible costs and advantages that are usually mentioned as affecting female choice criteria (Jennions and Petrie 1997) are unlikely to have been important in massrearing cages. There is no predation pressure, and males do not control access to any resources such as food, water, or oviposition sites. Difficulties regarding detection and discrimination of male signals such as sounds and odors during courtship would seem, if anything, to be greater in mass-rearing cages, and would thus seem to predict female preferences for longer rather than shorter courtships. Sexually active males are available on demand. Mating pairs are not harassed, nor are males aggressive other than at very close range (Briceño et al. 2000). Females do not need to compete with other females for access to food or oviposition sites. Females of a strain with few males did not evolve more rapid acceptance of copulation (Saul and McCombs 1993), as might be expected if encounters with males were limiting.

Indirect payoffs to females via offspring could be responsible for the change in female criteria. Longer courtships are at least somewhat more costly energetically, and might be possible indicators of overall male vigor; female bias toward shorter courtships would, if anything, favor less vigorous males, so greater survivorship or overall vigor benefits in offspring ("good genes") seem unlikely. By elimination, indirect Fisherian payoffs via the production of sons with increased chances of performing shorter, and thus uninterrupted courtships are the most probable explanation.

One previous study of $C$. capitata courtship found similar durations and high standard deviations in courtship duration under somewhat different captive conditions in a semidomesticated Hawaiian strain ( $\approx 10$ generations" in captivity, Whittier et al. 1994). There was no significant difference between durations of courtships preceding successful and unsuccessful mounts in this strain. Without data on the wild strain from which these flies were derived, it is not possible to judge whether or not this lack of difference represents a change similar to that seen in this study. The overall success rate of mounts in the Hawaiian flies was lower than that in the current study (11 versus $41 \%$ ), 
but differences in, among other things, the ages of the flies involved and the inclusion of data from repeated courtships involving the same males and females in the Hawaiian study preclude useful comparisons.

Apparent changes in female choice criteria have also been documented in island populations of C. capitata in Hawaii (Mclnnis et al. 1996) and another tephritid, Bactroccra cucurbitac Coquillett (Hibino and lwahashi 1991), where large numbers of sterile massreared males were released. Presumably, the selective factors in these cases were not indirect benefits to the female through superior phenotypes of adult offspring, but rather sharply increased egg hatching rates following matings with unsterilized males.

The changes in female behavior documented here are important for the controversy regarding the degree of genetic variation in the traits involved in sexual selection by female choice in natural populations. If, as some theoretical models suggest, there is little or no genetic variation in the male and female traits involved in female choice, then the probability that Fisherian runaway processes will occur is reduced (Parker 1984, Andersson 1994). C. capitata is native to Africa, and has apparently passed through at least 2 population bottlenecks before arriving in the New World, and New World populations have unusually low degrees of genetic variation (Huettel et al. 1980, Fuerst 1988). A still further reduction in genetic variability may well have occurred in the foundation of mass-reared strains. Even among these genetically impoverished flies, there was sufficient genetic variation in both male and female traits involved in sexual selection to permit relatively rapid responses in both sexes to selection imposed by mass-rearing conditions. Our data are in accord with other recent studies that have demonstrated genetic variance in male traits under sexual selection by female choice (Andersson 1994).

The large standard deviations in the durations of both successful and unsuccessful courtships in both this study and that of Whittier et al. (1994), combined with the multiple sexually dimorphic traits and the variety of stimuli that are produced by male C. capitata during courtship, suggest that courtship duration is only one of many factors that may influence female acceptance in C. capitata. Further work will be needed to elucidate female criteria, and how they change under mass-rearing conditions.

\section{Acknowledgments}

We thank Ricardo Gonzalez for technical assistance, and M. J. West-Eberhard for commenting on a preliminary version of the manuscript. The International Atomic Energy Agency, the Smithsonian Tropical Research Institute, and the Vicerrectoría de Investigación of the Universidad de Costa Rica provided financial support.

\section{References Cited}

Andersson, M. 1994. Sexual selection. Princeton University, Princeton, NJ.
Briceño, R. D., and W. G. Eberhard. 1998. Medfly courtship duration: a sexually selected reaction norm changed by crowding. Ethol. Ecol. Evol. 10: 369-382.

Briceño, R. D., D. Ramos, and W. G. Eberhard. 2000. Aggressive behavior in medflies (Ceratitis capitata) and its modification by mass rearing (Diptera: Tephritidae). J. Kans. Entomol. Soc. (in press).

Cayol, J. P. 1999. Changes in sexual behaivor and some life history traits of tephritid species caused by mass-rearing processes. In M. Aluja and A. Norrbom [eds.], Fruit flies (Tephritidae): phylogeny and evolution of behavior. CRC, Boca Raton, FL (in press).

Eberhard, W. G. 1999. Sexual behavior and sexual selection in the medfly, Ceratitis capitata. In M. Aluja and A. Norrbom [eds.], Fruit flies (Tephritidae): phylogeny and evolution of behavior. CRC, Boca Raton, FL (in press).

Eberhard, IV. G., and F. Pereira. 1995. The process of intromission in the Mediterranean fruit fly, Ceratitis capitata (Diptera: Tephritidae). Psyche 102: 99-120.

Feron, M. 1962. L’instinct de réproduction chez la mouche Mediterranéan des fruits Ceratitis capitata Wied. (Diptera: Trypetidae). Comportement sexuel. Comportement de ponte. Rev. Pathol. Veg. Entomol. Agric. France 41: 1-129.

Fuerst, P. A. 1988. Islands as models in population genetics, pp. 264-269. In J. Downhower [ed.], The biogeography of the island region of Western Lake Erie. Ohio State University, Columbus, $\mathrm{OH}$.

Hibino, Y., and O. lwahashi. 1991. Appearance of wild females unreceptive to sterilized males on Okinawa ls. in the eradication program of the melon fly, Dacus cucurbitae Coquillett (Diptera: Tephritidae). Appl. Entomol. Zool. 26: 265-270.

Huettel, M. P., A. P. Fuerst, T. Maruyama, and F. Chakraborty. 1980. Genetic effects of multiple bottlenecks in the Mediterranean fruit fly. Genetics 94: 547-548.

Jennions, M. D., and M. Petrie. 1997. Variation in mate choice and mating preferences: a review of causes and consequences. Biol. Rev. 72: 283-327.

McInnis, D. O., D. R. Lance, and C. G. Jackson. 1996. Behavioral resistence to the sterile insect technique by Mediterranean fruit flies (Diptera: Tephritidae) in Hawaii. Anu. Entomol. Soc. Am. 89: 739-744.

Miyatake, T., and D. Haraguchi. 1996. Mating success in Bactrocera cucubitae (Diptera: Tephritidae) under different rearing densities. Ann. Entomol. Soc. Am. 89: 284-289.

Parker, G. A. 1984. Sperm competiton and the evolution of animal mating strategies, pp. 1-60. In R. L. Smith [ed.], Sperm competition and the evolution of animal mating systems. Academic, New York.

Rössler, Y. 1975. Reproductive differences between laboratory-reared and field-collected populations of Mediterranean fruit fly, Ceratitis capitata. Ann. Entomol. Soc. Am. 68: 987-991.

Saul, S. H., and S. D. McCombs. 1993. Increased remating frequency in sex ratio distorted lines of the Mediterranean fruit fly (Diptera: Tephritidae). Anu. Entomol. Soc. Am. 86: 631-637.

Whittier, T. S, F. Y. Nam, T. E. Shelly, and K. Y. Kaneshiro. 1994. Male courtship success and female discrimination in the Mediterranean fruit fly (Diptera: Tephritidae). J. Ins. Behav, 7: 159-170.

Received for publication 7 June 1999; accepted 23 September 1999. 